differences show that delivery by lower segment caesarean section is more dangerous when the fetus presents by the breech, even in the best possible circumstances. The greater likelihood of a low Apgar score might be due to an inherent abnormality which in itself had caused the breech presentation but perhaps is more likely to be due to respiratory efforts before delivery of the head. A mature, healthy fetus is probably well able to withstand this extra insult, but for a breech-presenting fetus which becomes distressed during preterm labour the added hazard might be important. If the hypothesis that delay in delivery of the fetal head causes the depression is correct then this is another reason to consider delivery by classical caesarean section in cases of breech presentation where the fetus is already compromised.

I thank Professor B M Hibbard and Miss Joan Andrews for advice in planning this study, Mrs M Dauncey for extracting data from the Cardiff Birth Survey, and Mr R G Newcombe for the statistical analysis.

1 Hall JE, Kohl SG. Breech presentation. A study of 1456 cases. Am $\mathcal{J}$ Obstet Gynecol 1956;72:977-90.

2 Wright RC. Reduction in perinatal mortality and morbidity in breech delivery through routine use of caesarean section. Obstet Gynecol $1959 ; 14: 758-63$.

${ }^{3}$ Ingermarsson I, Westgren $M$, Svenningsen NW. Long-term follow up of preterm infants in breech presentation delivered by caesarean section. Lancet 1978 ;ii:172-5.

4 Collea JV, Chein C, Quilligan EJ. The randomised management of term frank breech presentation. A study of 208 cases. Am $\mathcal{f}$ Obstet Gynecol $1980 ; 137: 235-41$.

5 Rolf BB. The randomised management of term frank breech presentation: a study of 208 cases. Am $\mathcal{F}$ Obstet Gynecol 1980;137:244.

(Accepted 18 September 1980)

Department of Obstetrics and Gynaecology, Welsh National School of Medicine, Heath Park, Cardif CF4 4XN

JOHN P CALVERT, MRCOG, lecturer

\section{Effects of oral propranolol on parathyroid hormone secretion in chronic renal failure}

Parathyroid hormone secretion is stimulated by beta-adrenergic agents ${ }^{1}$ and this effect is blocked by propranolol. ${ }^{2}$ Acute infusion of propranolol in uraemic patients has been shown to inhibit secretion of parathyroid hormone, ${ }^{3}$ and a retrospective study has suggested that treatment with beta-blockers may protect against secondary hyperparathyroidism in haemodialysis patients. ${ }^{4}$ We report a prospective study designed to assess the long-term effects of oral propranolol on plasma parathyroid hormone concentrations in haemodialysis patients.

\section{Patients, methods, and results}

We studied four male and five female haemodialysis patients from 12 to 68 years. None of them were taking vitamin D compounds and all were taking aluminium hydroxide preparations. Their fasting plasma concentrations of calcium, phosphate, and immunoreactive parathyroid hormone were measured and they were then treated with propranolol by mouth. Seven received propranolol $40 \mathrm{mg}$ twice daily and the remaining two (both weighing under $45 \mathrm{~kg}$ ) $20 \mathrm{mg}$ twice daily. Isoprenaline infusion before treatment $(0.75-1.0 \mu \mathrm{g} / \mathrm{min})$ caused a significant increase in mean $( \pm S D)$ pulse rate of from $79 \pm 10$ to $96 \pm 15$ beats/min $(p<0.01)$. Repeat isoprenaline infusion during treatment caused little change in pulse rate $(68+13$ to $70 \pm 14)$. Fasting concentrations were again measured after six and 12 weeks' treatment. All blood samples were taken 48 hours after dialysis. Plasma calcium and phosphate were measured by standard methods and plasma immunoreactive parathyroid hormone by a previously described method. ${ }^{5}$ Statistical analysis was by the Wilcoxon matched pairs rank sum test.

Before treatment one patient was hypocalcaemic, four were normocalcaemic, and four were hypercalcaemic (range 1.68-3.1 mmol/1 (6.72-12.4 $\mathrm{mg} / 100 \mathrm{ml})$, normal range $2 \cdot 2-2 \cdot 63 \mathrm{mmol} / 1(8 \cdot 8-10 \cdot 52 \mathrm{mg} / 100 \mathrm{ml}))$. Eight patients were hyperphosphataemic (range 1.23-2.36 mmol/1 (3.91-7.5 $\mathrm{mg} / 100 \mathrm{ml})$, normal range $0.8-1.4 \mathrm{mmol} / 1(2 \cdot 5-4.5 \mathrm{mg} / 100 \mathrm{ml}))$. Seven patients had raised concentrations of immunoreactive parathyroid hormone (range $410-4000 \mathrm{ng} / \mathrm{l}$, normal range $250-950 \mathrm{ng} / \mathrm{l}$ ). The figure shows the effects of treatment on plasma calcium, phosphate, and immunoreactive parathyroid hormone concentrations expressed as a percentage of the initial value. There was no significant change in mean plasma calcium throughout treatment. The mean plasma phosphate concentration rose and was significantly higher than baseline values at six weeks $(p<0.05)$. Plasma concentrations of immunoreactive parathyroid hormone were below baseline values in seven out of nine patients at six weeks and in five out of six patients at 12 weeks. There was a mean fall in plasma immunoreactive parathyroid hormone at six weeks of $7.8 \%(p<0.05)$ and at 12 weeks of $14.7 \%$. There was no correlation between changes in plasma calcium or phosphate and changes in plasma immunoreactive parathyroid hormone.

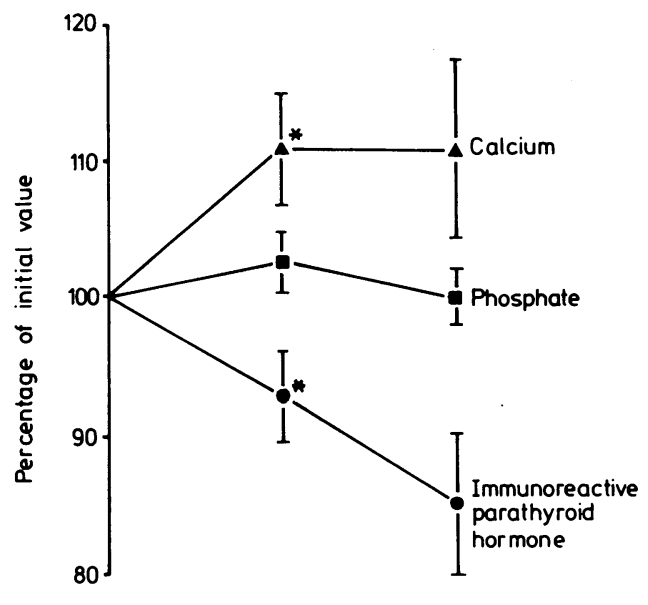

Time (weeks) 0

Patients (No)

6

12

Changes in plasma concentrations of calcium, phosphate, and immunoreactive parathyroid hormone in response to treatment with oral propranolol. Vertical bars indicate SEM. Asterisk indicates $\mathrm{p}<0.05$.

\section{Comment}

The beta-adrenergic-blocking activity achieved by the doses of propranolol given was significant as judged by the abolition of isoprenaline-induced rises in pulse rate. Plasma concentrations of immunoreactive parathyroid hormone fell during treatment, and this may indicate a direct effect of propranolol on beta-adrenergic receptors in parathyroid tissue. ${ }^{12}$ The degree of parathyroid gland suppression during acute propranolol infusion in uraemic patients was much greater $^{3}$ than that observed in this study. The differences may be accounted for by the significant rise in plasma phosphate concentrations which also occurred during this study. In normal circumstances this would lower plasma ionised calcium concentrations, which would tend to stimulate parathyroid hormone secretion. Hence the low plasma concentrations of immunoreactive parathyroid hormone seen may underestimate the actual degree of parathyroid hormone suppression achieved by propranolol. There were, however, only small reductions in concentrations of immunoreactive parathyroid hormone after three months' treatment, and we doubt whether propranolol has a role in the treatment of established hyperparathyroid bone disease in chronic renal failure.

${ }^{1}$ Fischer JA, Blum JW, Binswanger U. Acute parathyroid hormone response to epinephrine in vivo. $\mathcal{F}$ Clin Invest 1973;52:2434-40.

${ }^{2}$ Kukreja SC, Johnson PA, Ayala G, et al. Role of calcium and beta-adrenergic system in control of parathyroid hormone secretion. Proc Soc Exp Biol Med 1976;151:326-8.

${ }^{3}$ Coevoet B, Desplan C, Sebert JL, et al. Effect of propranolol and metoprolol on parathyroid hormone and calcitonin secretions in uraemic patients. Br Med f 1980;280:1344-6.

4 Caro JF, Besarab A, Burke JF, Glemon JA. A possible role for propranolol in the treatment of renal osteodystrophy. Lancet 1978 ;ii:451-3.

${ }^{5}$ Farrington K, Varghese Z, Moorhead JF. Human calcitonin in the treatment of renal osteodystrophy. F Lab Clin Med 1980;96:399-406.

(Accepted 17 September 1980)

Department of Nephrology and Transplantation, The Royal Free Hospital, Pond Street, London NW3 2QG

K FARRINGTON, BSC, MRCP, senior registrar

J HAMZEH, MRCP, research fellow

Z VARGHESE, PHD, principal biochemist

J F MOORHEAD, FRCP, director

J

